\title{
TEXTILE FINISHING WITH CHITOSAN AND SILVER NANOPARTICLES AGAINST Escherichia coli ATCC 8739
}

\author{
Sevil ERDOĞAN \\ Trakya University, Keşan Vocational College, Laborant and Veterinary Health Programme, 22800, Keşan, Edirne, \\ TURKEY
}

Cite this article as:

Erdoğan S. 2020. Textile Finishing with Chitosan and Silver Nanoparticles against Escherichia coli ATCC 8739. Trakya Univ J Nat Sci, 21(1): 21-32, DOI: $10.23902 /$ trkjnat.641367

Received: 01 November 2019, Accepted: 07 February 2020, Online First: 17 February 2020, Published: 15 April 2020

Edited by:

Hatice Korkmaz Güvenmez

Corresponding Author:

Sevil Erdoğan

sevilerdogan@trakya.edu.tr

orcid.org/0000-0001-9148-911X

Key words.

Textile finishing process

Biomaterial

Nano-Ag

Antibacterial

Shrimp

Crayfish

\section{ORCID ID:}

Abstract: The finishing process with the antibacterial agents that protect the environment and human health is gaining importance. This study aims 1) to develop new generation antibacterial finishes using chitosan as a binder for nano-Ag coatings, 2) to determine the applicability of chitosan from shrimp and crayfish for textile production and 3) to contribute to environmentally friendly textile production. Chitosan from shrimp and crayfish wastes were used as adhesive in the binding of nanoparticles to fabric surfaces. The bonding properties of the nano-Ag particles on the fabric surfaces were investigated by Fourier transform infrared spectroscopy (FTIR), Scanning electron microscopy (SEM), and Energy dispersive x-ray spectroscopy (EDX) analysis. The antibacterial effectiveness of fabrics against Escherichia coli ATCC 8739 were tested according to JIS L 1902-2015 standard. The crayfish and shrimp chitosan formed a colorless film and coated the nano-Ag particles homogeneously on the cotton fabric. Antibacterial activity values were calculated as 3.10 and 5.74 for crayfish and shrimp chitosan coated cotton fabrics and as 5.37 and 5.10 for crayfish and shrimp chitosan+nano Ag coated cotton fabrics, respectively. Chitosan nanoAg coating which exhibited a good antibacterial activity (99.99\% reduction) against $E$. coli ATCC 8739 can be used in the manufacture of garments such as medical textiles, baby clothes, and underwear. The use of chitosan as a binder can reduce the use of chemicals in textile printing and pigment dying in finishing materials, pollutant discharges and emissions from industrial sources. Also, it presents innovative solutions for the protection of human and environmental health.

Özet: Çevreyi ve insan sağlığını koruyan antibakteriyel malzemelerle bitim işlemi son yıllarda önem kazanmaktadır. Bu çalışmanın amacı da 1) kitosanı nano-gümüş (Ag) kaplamalar için bağlayıcı olarak kullanarak yeni nesil antibakteriyel apreler geliştirmek, 2) karides ve kerevitlerden üretilen kitosanın tekstil üretimi için uygulanabilirliğini belirlemek ve 3) çevre dostu tekstil üretimine katkıda bulunmaktır. Çalışmada, karides ve kerevit atıklarından üretilen kitosan, $\mathrm{Ag}$ nanopartiküllerinin kumaş yüzeylerine bağlanmasında yapışkan olarak kullanılmıştır. Nano-Ag partiküllerinin kitosan aracılığıyla kumaş yüzeylerine bağlanma özellikleri Fourier dönüşümlü kızılötesi spektroskopi (FTIR), Taramalı elektron mikroskobu (SEM) ve Enerji dağılımlı x 1șını (EDX) analizleri ile incelenmiştir. Kumaşların Escherichia coli ATCC 8739' ye karş1 antibakteriyel aktiviteleri JIS L 1902-2015 standardına göre test edilmiştir. Çalıșmanın sonuçları kerevit ve karides kitosanlarının renksiz bir film oluşturduğunu ve Ag nanoparçacıklarını pamuklu kumaş üzerine homojen bir șekilde kapladığını göstermiștir. Kerevit kitosanı ve karides kitosanı ile kaplı pamuklu kumaşların antibakteriyel aktivite değerleri sırasıyla, 3,10 ve 5,74 olarak hesaplanırken, kerevit kitosanı+nano-Ag ve karides kitosanı+nano-Ag ile kaplanmış pamuklu kumaşların antibakteriyel aktivite değerleri sırasıyla 5,37 ve 5,10 olarak bulundu. E. coli ATCC 8739' ye karş1 iyi bir antibakteriyel aktivite sergileyen (\% 99,99 azalma) kitosan+nano-Ag kaplamalar, tıbbi tekstiller, bebek kıyafetleri ve iç çamaşırları gibi giysilerin imalatında kullanılabilir. Binder olarak kitosanın kullanılması, tekstil baskısında, pigment boyamada, terbiye maddelerinde, kirletici deşarjlarında ve endüstriyel kaynaklı emisyonlarda kimyasalların kullanımını azaltabilir. Ayrıca, insan ve çevre sağlığının korunmasına yönelik yenilikçi çözümler sunar.

\section{Introduction}

Microorganisms can live in all kinds of environments including air, water and soil, and they can even survive in extreme environments such as deep-sea bottoms and

volcano mouths. They are most commonly found in foods, living organisms, and clothing. In particular, cotton garments create favorable environments for bacteria with 
their natural fibrous, porous and hydrophilic structure and by providing moisture, temperature and nutrient in areas that come into contact with the skin (Akaydın \& Kalkanc1 2014, Zhou \& Kan 2014). The damage caused by microorganisms affects cotton fabrics more than other types of fabrics. Microorganisms not only cause odor formation and deterioration in the fabric, but also they cause dermal infections and allergic reactions (Tania et al. 2019). Colclasure et al. (2015) reported that clinically important coliform bacteria, such as Escherichia coli, can be present in significant amounts, especially on moistureretaining fabrics at room temperatures and in dark conditions and can survive for long periods. The proliferation on the fabric surface of this pathogen bacteria, which often causes gastrointestinal infections and outbreaks of food poisoning, needs to be controlled (Pevzner 2018). Therefore, this study focused on E. coli ATCC 8739 and developing textile finishing agents which would give antimicrobial activity to fabrics against this pathogenic bacteria.

Polymers are materials used in various applications and are of great importance in human life. Although industrial polymers have high potential properties, they create pollution as a result of not being destroyed by natural processes (Sher et al. 2013). This led researchers to renewable natural resources. Chitosan is a renewable biopolymer and it is produced by deacetylation of chitin, which is a protective and supportive structure in a wide variety of living groups such as crustaceans, mollusks, insects and fungi (Abdou et al. 2008, Erdogan \& Kaya 2016, Erdogan et al. 2017, Arrouze et al. 2017, Zhang et al. 2017, Song et al. 2018). Chitosan, which is a natural, biocompatible, biodegradable and non-toxic biopolymer, can be easily modified and functionalized thanks to its reactive hydroxyl and amino groups and it is used in diverse application areas (Anitha et al. 2014). Furthermore, thanks to these reagent groups, chitosan can be used in finishing and in textile dyeing (Islam \& Butola 2019). The cationic structure of chitosan plays an active role by exhibiting antimicrobial, antioxidant, antitumor and anticancer properties which enables it to be used as a therapeutic and antibacterial agent in many medical applications (Anitha et al. 2014).

Nanoparticles are used for odor removal on textiles or controlled release of antifungals and biocides (Rivero et al. 2015). Nanoparticles with antimicrobial or antibacterial properties can be added to the fibers with nanotubes for long-term protection or can be added to polymers in fabric coatings. Nanosilver (nano-Ag) attracts attention with its antibacterial properties that provide an easy and lasting effect on pathogenic microorganisms like bacteria and viruses that threaten human health (Morones et al. 2005, Panacek et al. 2006). Besides, silver (Ag) nanoparticles are commercially used as a broad-spectrum antibiotic agent and exhibit high performance even at low concentrations (Govindan et al. 2012, Chen et al. 2014). Since they have a strong antibacterial effect and do not create toxic effects, $\mathrm{Ag}$ and
Ag compounds can be used on many surfaces and areas where harmful microorganisms are abundant during production or after production (Becenen \& Altun 2016). Therefore, in this study, we coated cotton fabric samples with nano-Ag particles using chitosan as a crosslinker and investigated the antibacterial activity of nano-Ag and chitosan together against E. coli.

Recently, a large amount of studies have been carried out to give antimicrobial properties to textile samples (Wang et al. 2016, Souza et al. 2017, Scacchetti et al. 2018, Fan et al. 2018, Rehan et al. 2018, Xu et al. 2019). In these studies, chitosan was coated on fabric surfaces via various crosslinkers or using different techniques as composite prepared with various antibacterial agents. Furthermore, in most antibacterial textile coatings, fabric samples are pretreated and modified using various chemicals before or during coating. In this study, nano$\mathrm{Ag}$ particles were coated via chitosan on fabric made of $100 \%$ cellulose without pretreating and using additional chemicals. Thus, we strove to achieve in a single step both to bond nano-Ag on the fabric surface and to give antibacterial properties to the fabric, by evaluating environmental waste materials and reducing the use of chemicals. Previous studies pointed out that chitosan source affects both the physicochemical and biological properties of chitosan (Rinaudo 2006). However, there is no comparative study on how chitosan obtained from different sources affect the antibacterial performance of fabric samples. In this study, we tested the antibacterial activity of fabric samples coated with chitosan produced from two different sources (saltwater shrimp Parapenaus longirostris (Lucas, 1846) and freshwater crayfish Astacus leptodactylus (Eschscholtz, 1823)) by using the same method under controlled and standard conditions. Also, unlike other studies, we used JIS L 1902: 2015 test method, instead of the commonly used ATCC 147 and AATCC 100 tests for determining antibacterial activity of chitosan+nano-Ag coatings. Thus, we expect to obtain more realistic and accurate results with this method which reflects the real-life conditions by keeping limited the amount of nutrients in the medium.

This study aims 1) to develop new generation antibacterial finishes using chitosan as a binder for nanoAg coatings, 2) to determine the applicability of chitosan produced from shrimp and crayfish for textile production and 3) to contribute to environmentally friendly textile production.

\section{Materials and Methods}

\section{Materials used in the experiment}

Waste shells forming the exoskeleton of shrimp and crayfish were utilized as sources of chitin and chitosan. Chitin was isolated by the chemical synthesis method from waste shells of shrimp (Parapenaus longirostris (Lucas, 1846)) purchased from a local market and crayfish (Astacus leptodactylus (Eschscholtz, 1823)) caught from Altınyazı dam lake (in Turkey). Isolated chitin were then converted to chitosan by deacetylation. 
Pretreated optic white cotton calico fabric made of $100 \%$ cotton yarn was used to apply chitosan and nano-Ag particles. Nano-Ag particles $(\leq 100 \mathrm{~nm}$ particle size, purity: $99.5 \%$ ) were purchased from Sigma Aldrich. The nanoparticles were vortexed for 10 seconds before use to ensure homogenization of the particles.

\section{Chitin isolation and chitosan production}

Shrimp and crayfish waste shells were cleaned with water to remove impurities and then rinsed with distilled water and dried in the oven at $50{ }^{\circ} \mathrm{C}$ for 2-3 days. Chitin isolation and chitosan production from both organisms were performed following the same procedure (Fig. 1). Firstly, crushed shrimp and crayfish shells (40 g) were refluxed with $1.8 \mathrm{M} 400 \mathrm{~mL} \mathrm{HCl}$ at $60-70^{\circ} \mathrm{C}$ for 6 hours at $700 \mathrm{rpm}$. The acid-treated shells were then filtered through common filter paper and rinced with pure water until free of acid. The demineralized shells were then treated with $1.8 \mathrm{M} 400 \mathrm{~mL}$ of $\mathrm{NaOH}$ at $70^{\circ} \mathrm{C}$ for 20 hours by stirring at $700 \mathrm{rpm}$. The mixture was then filtered again and rinsed with distilled water until the $\mathrm{pH}$ was neutral.
Employing these two processes, minerals and proteins in waste shells were removed and chitin was obtained. Since the shells of both organisms contained a high percentage of astaxanthin pigment, the chitin obtained from these organisms were subjected to decolorization process. Decolorization was achieved by treating chitin samples with a mixture of $200 \mathrm{~mL}$ including chloroform, methanol and distilled water in a 1:2: 4 ratio, respectively. This was accomplished by stirring the mixture containing chitin samples at $800 \mathrm{rpm}$ for 2 hours at room temperature. Finally, the mixture was filtered and the collected chitin samples were washed with pure water and dried in the oven at $50{ }^{\circ} \mathrm{C}$.

The dried chitin samples were refluxed with $70 \%$ $\mathrm{NaOH}$ solution for 3 hours at $150{ }^{\circ} \mathrm{C}, 800 \mathrm{rpm}$ to obtain chitosan (Fig. 1). The deacetylated chitin samples were then washed continuously with pure water and the process continued until the samples were cleared of base and reached $\mathrm{pH}: 7.0$. The obtained chitosan sample was placed in a petri dish and dried at $50{ }^{\circ} \mathrm{C}$ in an oven.

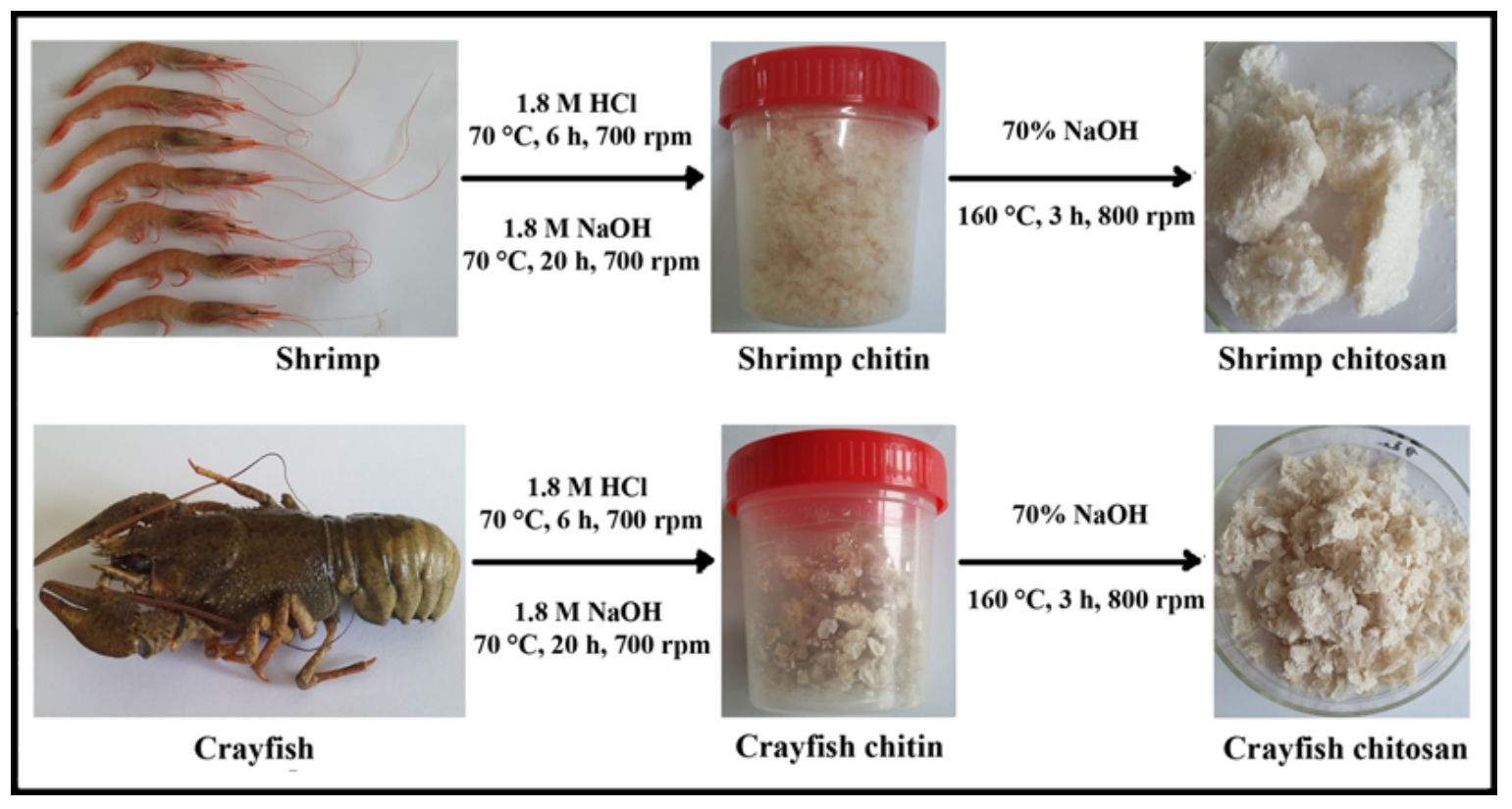

Fig. 1. Scheme illustrating the production of chitosan from shrimp and crayfish.

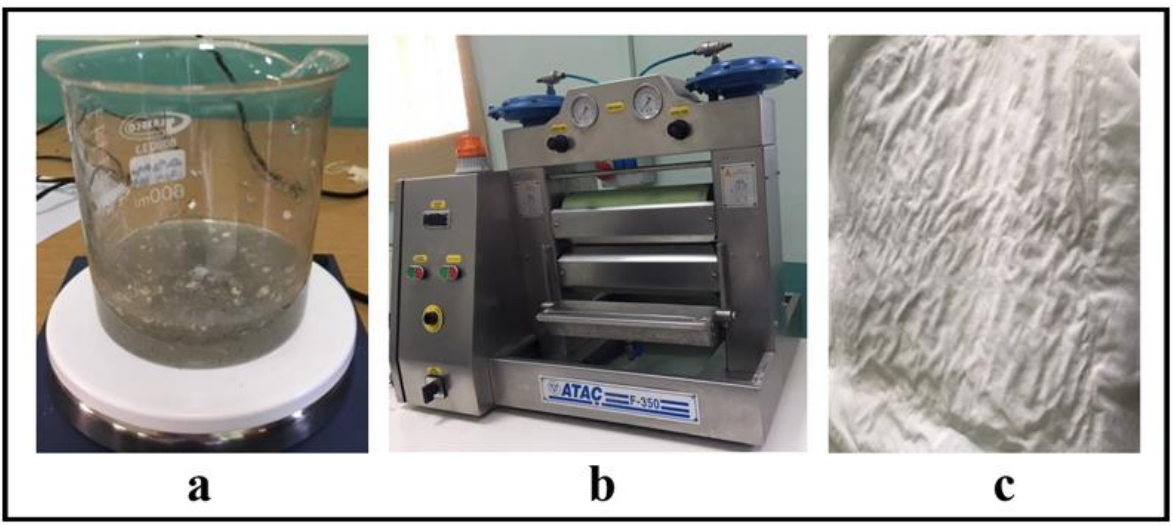

Fig. 2. Application of nano-Ag to fabric through chitosan. a) Dissolution of chitosan b) Coating machine c) Coated fabric. 
Coating of cotton fabric with chitosan and nano-Ag mixture

A mixture including $10 \%$ by weight of chitosan and $1 \%$ acetic acid $\left(\mathrm{CH}_{3} \mathrm{COOH}\right)$ was prepared using chitosan. To dissolve the chitosan, the mixture was heated at $40{ }^{\circ} \mathrm{C}$ by stirring at $400 \mathrm{rpm}$ for 5 hours (Fig. 2a). Nano-Ag ( $0.5 \%$ by weight) was added to the prepared chitosan solutions and stirring was continued for a further 1 hour. The solutions containing chitosan and nano-Ag were impregnated with the pad-dry method on fabrics in the Ataç Brand foular machine with 100\% squeezing pressure (Fig. 2b). After impregnation, the fabrics were dried at $105-110^{\circ} \mathrm{C}$ and then fixed in the same machine at $120^{\circ} \mathrm{C}$ (Fig. 2c).

\section{Fourier Transform Infrared Spectroscopy (FTIR)}

Chemical structure characterization was performed to confirm that the material isolated from shrimp and crayfish was chitin. Furthermore, to determine whether the chitosan+nano-Ag mixture was coated on cotton fabrics, changes in chemical bonds were determined by FTIR peaks. FTIR spectra were obtained with PerkinElmer ATR FTIR device in the range of 4000 to $400 \mathrm{~cm}^{-1}$ wavelength. Surface analyses of chitosan nano-Ag coated fabric samples were performed in Trakya University Technology Research Development Application and Research Center (TUTAGEM).

Scanning electron microscopy (SEM) and Energydispersive $X$-ray analysis $(E D X)$

The success of chitosan obtained from shrimp and crayfish wastes in coating nano-Ag particles on fabric samples, bonding properties between fabric and coating and the change in fabric topography was determined by SEM and EDX analyses. Whether shrimp and crayfish chitosan was successfully coated on the cotton fabric was investigated by taking surface images at different magnifications. SEM images were taken with ZEISS LEVO LS 10 and FEİ QUANTA FEG 250 SEM microscopes at 500X, 1000X and 2000X magnifications. Dispersions of nano-Ag particles on the cotton fabric surface were examined by energy dispersive $\mathrm{x}$-ray analysis.

Determination of the antibacterial activity of chitosan + nano-Ag treated cotton fabrics

The antibacterial efficacy of chitosan+nano-Ag coated fabric samples against Escherichia coli ATCC 8739 was tested by the JIS L 1902-2015 standard test method (JIS L 1902). It is a quantitative method used to test the ability of antibacterial finished fabrics to inhibit microbial growth and kill microorganisms.

Two experimental groups as shrimp chitosan and crayfish chitosan-coated samples were formed according to chitosan source. These samples were then subdivided into 2 groups with and without nano-Ag. The antimicrobial activity of the fabric samples in each group against $E$. coli was analyzed according to the following method.
Samples ( $0.4 \mathrm{~g}$ in weight) were cut from the cotton fabric coated with chitosan and nano-Ag and placed in test tubes. Before the experiment, the fabric samples were sterilized at $121{ }^{\circ} \mathrm{C}$ for 15 minutes. As the test method, the absorption method was applied in which the bacterial suspension was directly grafted onto the samples. The fabric samples were then inoculated with the test organism of $0.2 \mathrm{~mL}$ at a concentration of $2.9 \times 10^{5}$ $\mathrm{CFU} / \mathrm{mL}$ grown in a liquid culture medium. Initial microbial concentrations were determined at time zero. Bacteria were counted according to Plate Count Method. The control and test fabric samples inoculated with $E$. coli were then incubated in closed containers at $37 \pm 2{ }^{\circ} \mathrm{C}$ for 18-24 hours. After that, final bacterial concentrations were determined. The reduction of bacteria in initial concentrations and the control samples were calculated.

The bacterial growth rate for the control sample was calculated according to the formula $\mathrm{F}=\mathrm{Ct}-\mathrm{C}_{0}$ and for the test sample it was calculated according to the formula $G$ $=\mathrm{Tt}-\mathrm{T}_{0}$, where

A is antibacterial activity,

$\mathrm{C}_{0}$ is the average logarithmic value of the untreated sample immediately after inoculation ( $0 \mathrm{~h}$ contact time),

$\mathrm{Ct}$ is the average logarithmic value of the untreated sample after 24 hours,

$\mathrm{Tt}$ is the average logarithmic value of the treated test sample after 24 hours and

$\mathrm{T}_{0}$ is the average logarithmic value of the treated test specimen immediately after inoculation (0 hours).

Antibacterial activity value was calculated according to the formula $\mathrm{A}=\mathrm{F}-\mathrm{G}$.

According to JIS L 1902 method, if $2 \leq \mathrm{A}<3$ then the tested sample has an effect and if $A \geq 3$, then it has a strong effect.

\section{Results and Discussion}

\section{Chitosan as a binder}

The crayfish and shrimp chitosan, used as binding agents in the coating of cotton fabrics, were treated with $1 \%$ acetic acid to form water-soluble solutions. Although there was no significant difference between the solutions, chitosan produced from shrimp wastes was easier to prepare. The shrimp chitosan produced a more homogeneous solution than crayfish chitosan and it was more easily applied to the fabric. However, the distribution of nano-Ag particles on the fabric surface was more homogeneous in the coating with crayfish chitosan compared to coatings with shrimp chitosan. Analysis results of crayfish chitosan coating were comparable to the finding of Xu et al. (2019) who used carboxymethyl chitosan to fix nano-Ag particles to the cotton fabric surface. Crayfish chitosan was found to be a more suitable to deposite nano-Ag particles on the fabric surface than shrimp chitosan in terms of homogeneous distribution of nanoparticles. 
In coating with chitosan, the film layer on the fabric surface was colorless and did not change the color of the fabric. The film layer did not show adhesive properties after drying. Furthermore, after treatment, the chitosan solution was easily removed from the machine rollers. The chitosan used as the binding agent had no adverse effects on the binding quality of the nano-Ag particles to the fabric. These are the expected properties of fiberbonding materials which provide the adhesion of the finishing agent to the fiber in textile finishing processes. For this reason, chitosan produced from shrimp and crayfish waste shells by the chemical method were found to be suitable for use as binder polymer in nano-Ag coatings. The use of chitosan, which is a natural and biodegradable polymer, as a binder in textile will enable to minimize the negative effects of chemicals used in finishing enterprises to the environment and contribute to environmentally friendly textile production.

\section{FTIR analysis results}

FTIR analysis was performed to characterize the chitin samples isolated from shrimp and crayfish waste shells and to confirm whether the shrimp and crayfish chitosans formed a bond between nano-Ag and cotton fabric. Chitin is available in 3 different forms as alpha, beta and gamma chitin in nature (Lavall et al. 2007). In the FTIR spectrum of alpha chitin, the two absorption bands at 1650 and 1620 $\mathrm{cm}^{-1}$ refer to the stretching of amide I, and the absorption band at $1550 \mathrm{~cm}^{-1}$ is attributed to amide II (N-H bending) (Focher et al. 1992, Lavall et al. 2007). The band at 650 $\mathrm{cm}^{-1}$ was referred to the $\mathrm{C}=\mathrm{O}$ group hydrogen-bonded to $\mathrm{N}-\mathrm{H}$ of the neighboring chain (Dahmane et al. 2016). In our study, characteristic absorption bands showing stretching of amide I of chitin were observed at 1653 and $1620 \mathrm{~cm}^{-1}$ for shrimp chitin and at 1655 and $1619 \mathrm{~cm}^{-1}$ for crayfish chitin. Another characteristic band showing amide II stretching was recorded at $1552 \mathrm{~cm}^{-1}$ for both shrimp and crayfish chitin (Fig. 3). This also shows that the isolated chitin is in alpha form.

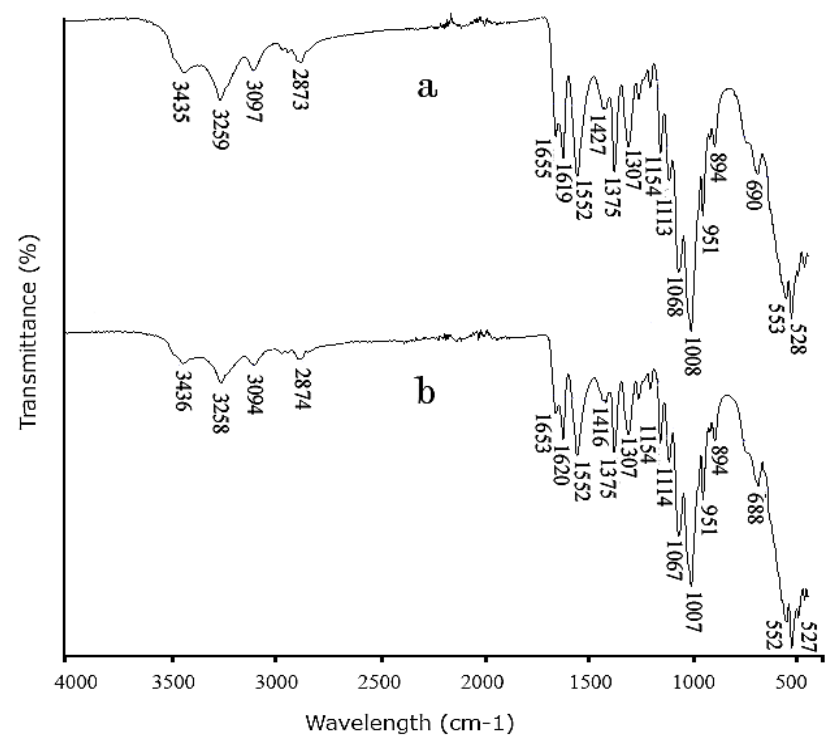

Fig. 3. FTIR spectra of isolated chitin samples. a) from crayfish, b) from shrimp.



Fig. 4. FTIR images of cotton fabric coated with nano-Ag via chitosan. a) Shrimp chitosan+nano-Ag coated fabric, b) Crayfish chitosan+nano-Ag coated fabric, c) Crayfish chitosancoated fabric and d) Shrimp chitosan-coated fabric.

The FTIR spectra of coatings using shrimp and crayfish chitosan as binders are presented in Fig. 4. Previous studies showed that the characteristic absorption bands of cellulose in the FTIR spectra of cotton fabric were observed at 1430 $\mathrm{cm}^{-1}$ (C-H wagging), $1364 \mathrm{~cm}^{-1}$ (C-H bending), $1105 \mathrm{~cm}^{-1}$ (C-O-C, asymmetric bridge stretching), and 1160, 1060 and $1028 \mathrm{~cm}^{-1}$ (C-O stretching) (Xu et al. 2019). These peaks were observed in our chitosan and nano-Ag coated fabric samples at 1428-1428, 1361-1368, 1105-1109, 1158-1162, 1035-1055 and 1026-1030 $\mathrm{cm}^{-1}$, respectively. Mujtaba et al. (2016) observed a sharp peak for cellulose at 3336 and $3330 \mathrm{~cm}^{-1}$ attributed to the hydroxyl group and hydrogen bond, respectively. They also observed a peak at around $896 \mathrm{~cm}^{-1}$ correspondings to the structure of the glucose ring. These peaks were observed in our samples at 3335 and $3336 \mathrm{~cm}^{-1}$, and between 894 and $896 \mathrm{~cm}^{-1}$, respectively. The characteristic absorptive peaks for chitosan are I. carbonyl $(\mathrm{C}=\mathrm{O})$ band around $1650 \mathrm{~cm}^{-1}$ and II. amide $(\mathrm{NH}$ 2) band around $1590 \mathrm{~cm}^{-1}$ (Chen et al. 2014). When considering the FTIR spectra of the cotton fabrics coated with nano-Ag via chitosan, it was seen that the peak at 1650 $\mathrm{cm}^{-1}$ was shifted to 1633,1641 and $1647 \mathrm{~cm}^{-1}$ and the peak at $1590 \mathrm{~cm}^{-1}$ was shifted to 1538,1562 and $1550 \mathrm{~cm}^{-1}$. Murugan et al. (2017) reported that the FTIR spectra of $\mathrm{Ag} /$ chitosan composite differed from those of chitosan. The characteristic peaks of chitosan at 1658 and $1600 \mathrm{~cm}^{-1}$ assigned to the stretching vibrations of amide $\mathrm{C}-\mathrm{O}$ bonds sharply reduced and shifted to $1628 \mathrm{~cm}^{-1}$. Another study stated that the intensity of the peak at $3434 \mathrm{~cm}^{-1}$ referred to the hydroxyl and primary amino groups decreased because 
the amino and hydroxyl groups of chitosan chelated the nano-Ag particles (Chen et al. 2014).

When compared to the FTIR bands of crayfish and shrimp chitosan-coated cotton fabric (Figs 4c, 4d), changes were observed in the FTIR spectra of chitosan+nano Ag coated fabric samples (Figs 4a, 4b). As mentioned in previous studies, these shifting in the FTIR peaks indicate that the formation of coordination bonds between the amine groups of the chitosan and the nanoAg particles ( $\mathrm{Xu}$ et al. 2019), or that Ag is chelated by both amino and hydroxyl groups of the chitosan (Chen et al. 2014). This shows that nano-Ag is chemically bonded to cotton fabric via shrimp and crayfish chitosan.

\section{$\underline{\text { SEM and EDX analysis results }}$}

Scanning electron microscopy was used to evaluate the presence and bonding properties of chitosan and nanoAg particles on cotton fabric. SEM and EDX images of cotton fabrics before and after the coating showed that these fabrics were successfully coated with shrimp and crayfish chitosan and nano-Ag (Figs 5, 6). Zhou \& Kan (2014) observed that while the SEM images of the fibers in the pure cotton fabric were smooth, the SEM images of the chitosan-coated cotton fibers were not smooth. Our study indicates the same results. Also, in this study, the surface of crayfish chitosan-coated fabric appeared to be rougher (Fig. 5b) than the surface of shrimp chitosancoated fabric (Fig. 5c).

The shrimp and crayfish chitosans adhered to the cellulose fibers and formed a film by surrounding the nano-Ag particles (Figs 6a, 6d). Other studies have also confirmed that chitosan forms a film on a cotton fabric surface (Chattopadhyay \& Inamdar 2013). In the coating with crayfish chitosan, nano-Ag particles exhibited a relatively homogeneous distribution (Fig. 6f), while nano$\mathrm{Ag}$ particles coated on the fabric surface with shrimp chitosan appeared to aggregate (Fig. 6c). Govindan et al. (2012) stated that the FESEM image of chitosan-Ag nanocomposite showed that nano-Ag particles were wrapped with chitosan and agglomeration was observed. The authors also reported that agglomeration can be prevented by slowly dissolving the chitosan a good while and dispersing $\mathrm{Ag}$ in the chitosan with stirring for a longer time and thereby, nano-Ag particles will be embedded in a chitosan matrix.
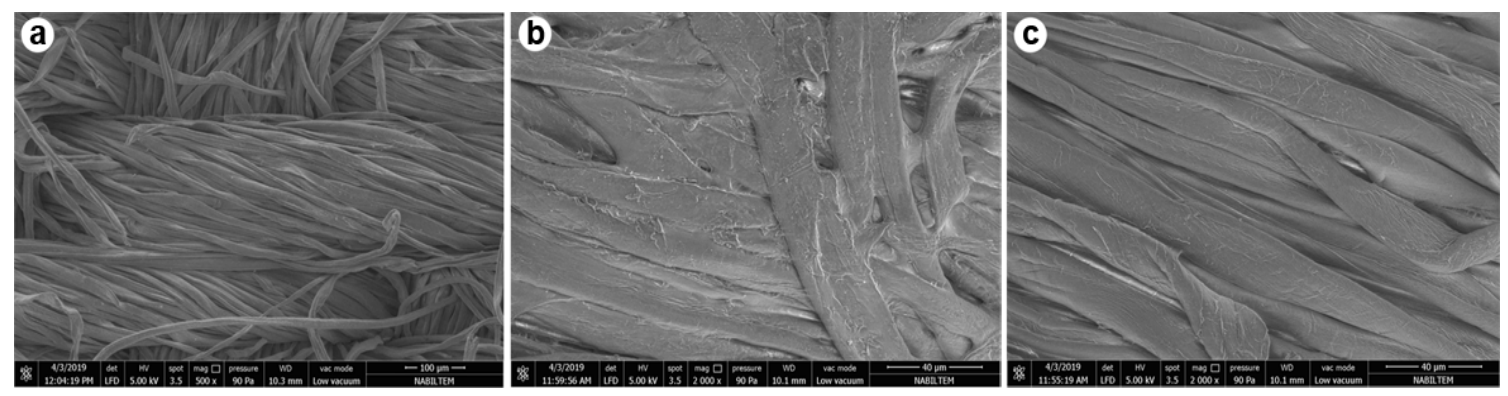

Fig. 5. SEM images of cotton fabric surfaces. a) Uncoated fabric b) Crayfish chitosan-coated fabric c) Shrimp chitosan-coated fabric.
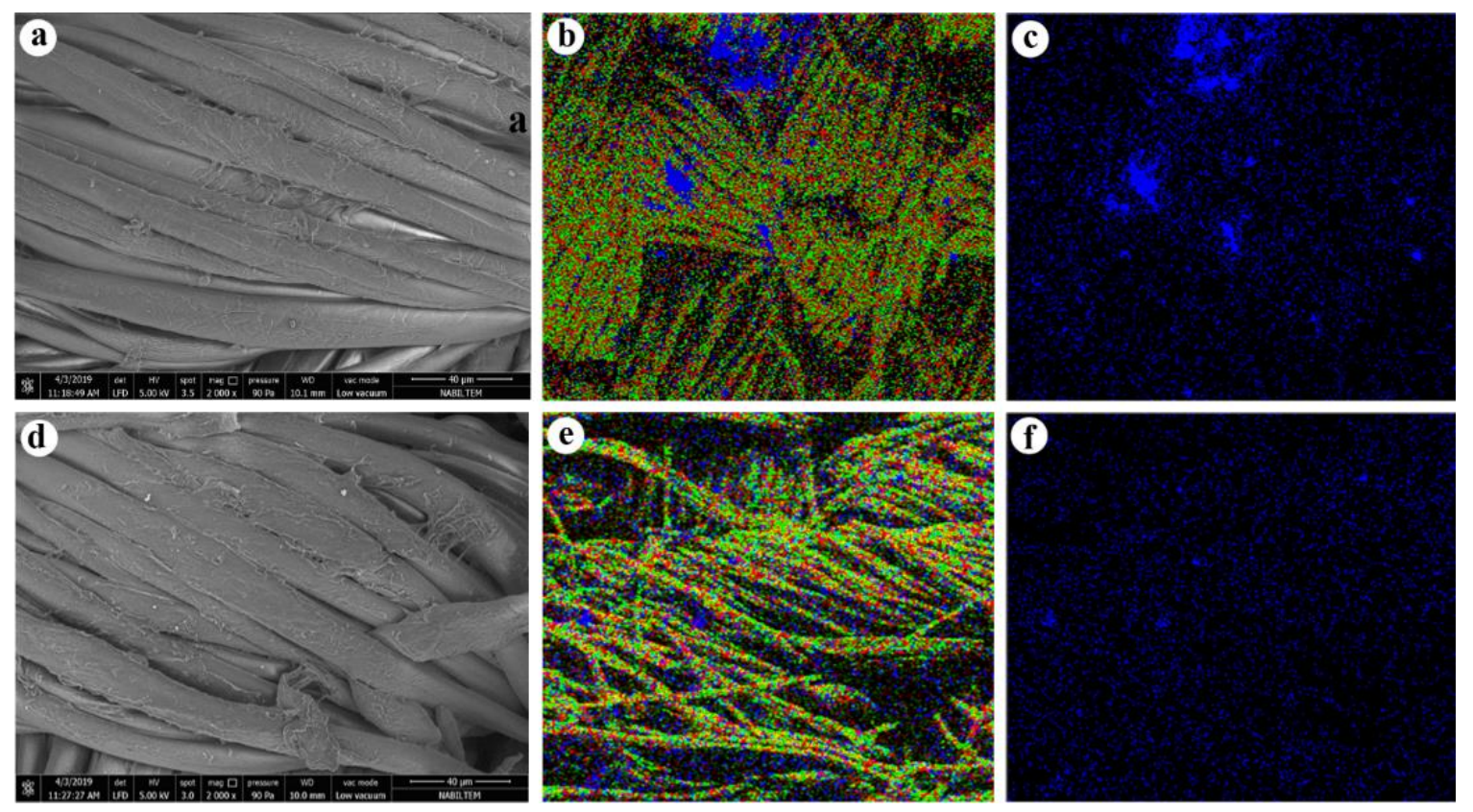

Fig. 6. SEM and EDX images of chitosan and nano-Ag coated cotton fabrics. a) SEM image of shrimp chitosan+Nano-Ag coated fabric, b and c) EDX images of shrimp chitosan+Nano-Ag coated fabric (C, O, Ag elements and Ag element only), d) SEM image of crayfish chitosan+Nano-Ag coated fabric, e) and f) EDX images of the crayfish chitosan+Nano-Ag coated fabric (C, O, Ag elements and Ag element only). 
Table 1. Elemental composition of chitosan-nano Ag coatings.

\begin{tabular}{lccccccc}
\hline \hline & Element & Wt \% & At \% & K-Ratio & Z & A & F \\
\hline \hline & $\mathrm{C}$ & 46.22 & 53.40 & 0.2373 & 1.0076 & 0.5094 & 1.0004 \\
Shrimp chitosan + Nano-Ag coating & $\mathrm{O}$ & 53.73 & 46.60 & 0.1052 & 0.9935 & 0.1970 & 1.0000 \\
& $\mathrm{Ag}$ & 0.046 & 0.006 & 0.0009 & 0.7667 & 2.7016 & 1.0000 \\
& Total & 100.00 & 100.00 & & & & \\
& $\mathrm{C}$ & 46.26 & 53.44 & 0.2377 & 1.0076 & 0.5096 & 1.0004 \\
Crayfish chitosan + Nano-Ag coating & $\mathrm{O}$ & 53.67 & 46.54 & 0.1049 & 0.9935 & 0.1968 & 1.0000 \\
& $\mathrm{Ag}$ & 0.06 & 0.01 & 0.0013 & 0.7667 & 2.6772 & 1.0000 \\
& Total & 100.00 & 100.00 & & & & \\
\hline \hline
\end{tabular}

EDX analysis was performed to observe the elemental distributions on the surface of cotton fabrics coated with chitosan and nano-Ag particles and to detect the presence of nano-Ag particles on the fabric surface. Previous studies reported that $3 \mathrm{keV}$ peaks attributed to the $\mathrm{Ag}$ formation signal were observed in the EDX analysis graph of the nano-Ag deposited fabric (Gharibshahi et al. 2017, Tania et al. 2019). In this study, the presence of the peak of the Ag element in the EDX spectrum of cotton fabrics confirmed the deposition of silver nanoparticles on the fabric. Table 1 shows the distribution by weight of $\mathrm{C}, \mathrm{O}$ and nano-Ag particles on the fabric surface. In previous studies, the $\%$ by weight of nano-Ag particles deposited on the fabric surface was recorded as $0.006 \%$ (Gharibshahi et al. 2017) and 0.10\% (Arif et al. 2015). In our study, the weight of nano-Ag on the surface of the fabric was $0.046 \%$ in the coating with shrimp chitosan and $0.06 \%$ in the coating with crayfish chitosan. Although the amount of nano-Ag particles used in coatings is same, it appears that crayfish chitosan binds a higher amount of nano-Ag particles to the fabric in comparison to shrimp chitosan. This may be due to the acquisition of EDX images from selected regions and the aggregation of shrimp chitosan in some regions.

Antibacterial activity results of cotton fabric coated with chitosan and nano- $A g$

Antibacterial activity of cotton fabric coated with chitosan and nano-Ag against E. coli ATCC 8739 was investigated by JIS L 1902-2015 Quantitative standard test method.

Various standard tests have been developed and used so far to determine the antibacterial efficacy of textile products. The most commonly used are qualitative tests such as ISO 20645: 2004, AATCC 147: 2004, and halo method of JIS L 1902: 2008, and quantitative tests such as AATCC 100: 2004, absorption method of ISO 20743: 2007, and absorption method of JIS L 1902: 2008 (Palamutçu et al. 2008, Pinho et al. 2011). Qualitative tests are inadequate to accurately determine the antibacterial activity of fabric samples. In quantitative methods, the reduction of bacterial growth is calculated by comparing it to a control sample and the value of the antibacterial activity can be accurately determined (Torlak 2008, Pinho et al. 2011). Pinho et al. (2011) reported that the JIS L 1902-The adsorption method gives very sensitive and accurate results. Palamutçu et al. (2008) stated that JIS L 1902-2002 standard is applied considering the moisture content and nutrient amount on textiles under normal clothing conditions. The authors also stated that tests are performed in a situation similar to real-life conditions and that the amount of nutrients in the medium is kept limited. Thus, the antibacterial activity of textile samples with antibacterial finishing is tested in an environment similar to real-life conditions. Table 2 presents comparative antibacterial activity values of cotton fabrics coated with nano-Ag via chitosan according to JIS L 1902-2015.

The antibacterial activity value (A) of the fabric samples covered with crayfish and shrimp chitosan were calculated as 3.10 and 5.74, respectively, considering bacterial growth rates. According to JIS L 1902-2015, if A $>3$, the tested sample is considered to exhibit a very good antibacterial activity (99.9\% reduction). In this case, the fabrics coated with crayfish and shrimp chitosan showed high antibacterial activity against $E$. coli ATCC 8739. Besides, shrimp chitosan exhibited higher antibacterial performance than crayfish chitosan. The antibacterial activity values of cotton fabric samples coated with nano-Ag via shrimp and crayfish chitosan were calculated as 5.10 and 5.37 , respectively. The reduction ratio of $99.99 \%$ in bacterial viability indicated that chitosan and nano-Ag composite coatings gave a strong antibacterial activity to cotton fabrics. The antibacterial activity values of fabrics coated with shrimp chitosan+nano-Ag and crayfish chitosan+nano-Ag were very close to each other. A significant improvement in the antibacterial activity of coatings containing chitosan+nano-Ag was observed in comparison to crayfish chitosan-coated fabric sample. Interestingly, shrimp chitosan coated fabric sample had the highest bacterial reducing rate among other fabrics.

The biocompatibility, biodegradability, non-toxicity, and antimicrobial and hypoallergenic properties of chitosan make it a suitable antibacterial agent for fabric surfaces (Zhou \& Kan 2014). It has been reported that the mechanism of the antibacterial action of chitosan is to bind to the cell wall of the bacteria through its positively charged amino groups and then to adhere to DNA and prevent the proliferation of bacteria (Govindan et al. 2012, Zhou \& Kan 2014). Results of various studies have been published on determination of antibacterial activity 
Table 2. Antibacterial activities of chitosan and nano-Ag coated cotton fabrics.

\begin{tabular}{|c|c|c|c|c|c|c|}
\hline \multirow[b]{2}{*}{ Samples } & \multicolumn{2}{|c|}{$\begin{array}{c}\text { Number of reproducing } \\
\text { microorganisms (CFU/sample) }\end{array}$} & \multicolumn{2}{|c|}{ Logaritmic reduction } & \multirow{2}{*}{$\begin{array}{c}\begin{array}{c}\text { Growth } \\
\text { value }\end{array} \\
* F=C t-C O \\
\text { and } \\
* G=T t-T 0 \\
\end{array}$} & \multirow{2}{*}{$\begin{array}{c}\begin{array}{c}\text { Antibacterial } \\
\text { activity value }\end{array} \\
\text { A=F-G } \\
\end{array}$} \\
\hline & $\begin{array}{l}\text { Contact time } \\
\text { (0 hours })\end{array}$ & $\begin{array}{l}\text { After incubation } \\
\text { (24 hours) }\end{array}$ & $\begin{array}{c}\log (C O) \\
\text { and } \\
\log (T 0) \\
\end{array}$ & $\begin{array}{c}\log (C t) \\
\text { and } \\
\log (T t) \\
\end{array}$ & & \\
\hline Uncoated cotton fabric & $7 \times 10^{4}$ & $6.8 \times 10^{7}$ & 4.85 & 7.83 & 2.99 & - \\
\hline $\begin{array}{l}\text { Shrimp chitosan and nano- } \\
\text { Ag coated fabric }\end{array}$ & $5.14 \times 10^{4}$ & $4 \times 10^{2}$ & 4.71 & 2.60 & -2.11 & $\begin{array}{c}A=5.10 \\
A>3 \\
\% 99.99\end{array}$ \\
\hline $\begin{array}{l}\text { Crayfish chitosan and } \\
\text { nano-Ag coated fabric }\end{array}$ & $4.84 \times 10^{4}$ & $2 \times 10^{2}$ & 4.68 & 2.30 & -2.38 & $\begin{array}{c}\mathrm{A}=5.37 \\
\mathrm{~A}>3 \\
\% 99.99\end{array}$ \\
\hline $\begin{array}{c}\text { Shrimp Chitosan coated } \\
\text { fabric }\end{array}$ & $4.1 \times 10^{4}$ & $2 \times 10^{2}$ & 4.61 & 2.30 & -2.31 & $\begin{array}{c}A=5.74 \\
A>3 \\
\% 99.99\end{array}$ \\
\hline $\begin{array}{l}\text { Crayfish Chitosan coated } \\
\text { fabric }\end{array}$ & $7.8 \times 10^{2}$ & $6 \times 10^{4}$ & 4.89 & 4.78 & -0.11 & $\begin{array}{c}\mathrm{A}=3.10 \\
\mathrm{~A}>3 \\
\% 99.9\end{array}$ \\
\hline
\end{tabular}

${ }^{*} F=C t-C_{0}$ : Growth value of uncoated fabric, ${ }^{*} G=T t-T_{0}$ : Growth value of coated fabric

of chitosan against various bacterial species (Jiang et al. 2010, Velmurugan et al. 2014, Tania et al. 2019). A study reported that chitosan-coated cotton fabric samples effectively inhibited the growth of Staphylococcus aureus and Klebsiella pneumoniae (Zhou \& Kan 2014). Şahan \& Demir (2016) reported that both chitosan and nano chitosan showed good antibacterial activity against $S$. aureus, E. coli and, K. pneumoniae. The results of this study indicated that crayfish chitosan showed high antibacterial effeciency against E.coli. Chitosan source affects the physico-chemical and biological properties of chitosan (Kumirska et al. 2011). The results of this study confirmed that the source of chitosan affects the biological properties of chitosan. Shrimp chitosan showed higher antibacterial performance than crayfish chitosan.

Nano-Ag particles have been widely used in the development of antibacterial textiles as effective antibacterial agents in recent years. Previous studies emphasized that Ag showed high biocompatibility and low toxicity with human cells in both ionic and colloidal forms (Marambio-Jones \& Hoek 2010). Since nano-Ag particles have a large surface area compared to their volume, they provide better contact with microorganisms and thus show good antibacterial properties (Velmurugan et al. 2014). A study reported that Nano-Ag particle coated cotton fabric has an excellent bacterial reduction for S. aureus (95\%) and E. coli (92\%) (Tania et al. 2019). Another study reported that the bacterial reduction rates of nano-Ag particle coated polyester fabrics were $99.7 \%$ for E. coli and $99.8 \%$ for S. aureus (Jiang et al. 2010). Both studies agree that nano-Ag particles exhibit excellent bacterial reduction and this effect related to the amount of nano-Ag particles deposited on the fabric surface. Microbial growth reduction values of nano-Ag containing composites for S. aureus and Pseudomonas aeruginosa were measured between 3.3-7.0 log CFU by JIS L 1902 method (Wiegand et al. 2015).
Chattopadhyay \& Inamdar (2013) reported that nano chitosan exhibited better antibacterial activity when treated with nano-Ag. Chen et al. (2014) reported that $\mathrm{Ag} /$ chitosan composites exhibit higher antibacterial activity against both the gram-positive bacteria $S$. aureus and Bacillus subtilis and the gram-negative bacteria $E$. coli and Salmonella choleraesuis than chitosan. The authors concluded that as well as the homogenously and well distribution of nano-Ag particles in the chitosan matrix, also synergistic effects of chitosan and nano-Ag particles caused Ag/chitosan composites to exhibit higher antibacterial activity. Arif et al. (2015) measured the antibacterial activity of fabric samples coated with chitosan+nano-Ag particles against $S$. aureus and E. coli and they found the bacterial reduction rates to be around 98-99\%. The authors stated that there was only a slight reduction in antibacterial activity even after 20 washes. $\mathrm{Xu}$ et al. (2019) coated carboxymethyl chitosan/Ag nanoparticle colloidal solution on a cotton fiber surface by the pad-dry-cure method using carboxymethyl chitosan as a binder. The authors stated that this coating was successfully coated on the fabric surface and imparted to the fabric significant antibacterial activity against $S$. aureus and E. coli. They discovered that even after 50 washes, the fabric retains its antibacterial activity. The results of relevant studies have shown that the application of chitosan together with $\mathrm{Ag}$ particles increases the antibacterial effect, and some results of our study are consistent with these studies. Crayfish chitosan+nano-Ag composite $(A=5.37)$ showed a higher antibacterial effect than crayfish chitosan (3.10). On the other hand, shrimp chitosan $(A=5.74)$ exhibited higher antibacterial activity then shrimp chitosan+nano-Ag composite $(A=5.10)$.

Evaluation of the chitosan and nano-Ag coatings in terms of human and environmental health

It is expected that antibacterial textile coatings are safe for human health and environmentally friendly. Chitosan is a biocompatible, biodegradable and non-toxic 
glycopolymer of biological origin. These properties of chitosan, which are used for treatment in many medical applications, have been emphasized in many studies (Li et al. 2016, Liang et al. 2018, Zhao et al. 2018). Chitosan is degradable within the body and it is safe and non-toxic (Dutta et al. 2004). In vertebrates, it is known that chitosan is mainly degraded by lysozyme and certain bacterial enzymes in the large intestine (Dash et al. 2011). It can also be degraded by many microorganisms in nature. Nano-Ag particles are also not prohibited and are one of the most suitable and commercially distributed nanomaterials in the world (Korani et al. 2015). Nano-Ag particles are widely used in medical and functional textiles, wound dressings, medical devices implanted for a long time, dental materials, water disinfectants, room sprays, laundry powders and deodorants due to their antibacterial and deodorizing properties (SCENIHR 2014, Korani et al. 2015, Burdusel et al. 2018). However, researches on the effects of nano-Ag particles on human health are limited (Korani et al. 2015). In vitro studies revealed that nano-Ag particles may show cytotoxic and genotoxic effects (SCENIHR 2014). Hartemann et al. (2015) reported that in vitro studies showed that nanosilver induced cytokine production in macrophages. Since there are few studies on the genotoxicity of nanoAg particles in vivo, it has been reported that the results of the present studies can not confirm the positive or negative effects of nano-Ag particles (SCENIHR 2014). The SCENIHR report states that the results of the studies are contradictory and some of them said that nano-Ag showed high cytotoxicity at doses between $2-5 \mu \mathrm{g} / \mathrm{mL}$, while the others showed almost no cytotoxicity at doses up to $100 \mu \mathrm{g} / \mathrm{mL}$ (SCENIHR 2014). Korani et al. (2013) showed that nano-Ag particles cause histopathological abnormalities in spleen, liver, and skin in animal experiments. In another study, colloidal nano-Ag particles were reported to be capable of producing a dosedependent toxic response in several organs (Korani et al. 2015). However, many studies point out that there is a lack of consistent and reliable data on the toxicity and biological behavior of nano-Ag particles in both in vitro and in vivo toxicity studies and further studies are needed to produce meaningful results (Korani et al. 2015, Hartemann et al. 2015, Burdusel et al. 2018). Researchers concluded that many parameters including deposition rates, particle size, surface area, dose taken, interaction with biological macromolecules, dispersion ratio, concentration, surface charge, morphology, surface oxidation, and conversion under biological conditions affect the toxicity of nano-Ag particles (SCENIHR 2014, Hartemann et al. 2015, Korani et al. 2015, Burdusel et al. 2018). Researchers emphasize the necessity of long-term studies with wide-range doses and different particle sizes to accurately determine the effects of nano-Ag particles on human health, (SCENIHR 2014, Korani et al. 2015).

When the published data on the subject is examined, it is seen that the findings related to the genotoxic and cytotoxic effects of nano-Ag particles are generally related to the intake of these nanomaterials as food supplements or drugs. However, in antibacterial textile products, nano-Ag is used on the fabric surface and it is only in contact with the skin. As in this study, it is generally used in low doses. In this study, SEM analyzes of chitosan and nano-Ag coated fabrics revealed that chitosan forms a film that encapsulates nano-Ag particles and fixes them to the fabric. The nanoparticles are embedded in the chitosan matrix. This is also noted in previous studies (Govindan et al. 2012, Chattopadhyay \& Inamdar 2013). Chitosan is already a natural biomaterial and it prevents direct contact of nano-Ag on the fabric surface with the skin. Thus, it prevents possible toxic effects by preventing or limiting the penetration of nanoAg particles into the body. Edward-Jones (2009) stated that although, Ag element has been used intensively in the treatment of burns for 50 years, there are limited reported cases of $\mathrm{Ag}$ toxicity. The author states that $\mathrm{Ag}$ poisoning is dependent on $\mathrm{Ag}$ levels absorbed into the body in time and the amount absorbed by intact skin are lower than that absorbed by open wounds. Furthermore, SCENIHR (2014) reports that the uptake of nanomaterials via the skin is generally very low. Considering all these data, it can be concluded that the chitosan/nano-Ag coatings are safe for human health and environmentally friendly because they minimize the use of chemicals.

Little is known about the environmental impacts and hazards of nano-Ag particles in aquatic systems and it is not possible to draw general conclusions (SCENIHR 2014, Korani et al. 2015). Hartemann et al. (2015) state that nano-Ag particles released into the environment have a transformation such as aggregation, agglomeration, dissolution or silver chloride and silver sulfide formation. The author says that the chemical species of the transformed nano-Ag determines the bioavailability and toxicity of $\mathrm{Ag}$ in nature. He also stated that the effects of nano-Ag particles on soil can be vary depending on both nanoparticle and soil properties. As for water sources, Ag can be used to control the bacteriological quality of drinking water. The WHO (2017) report states that although there is insufficient data to obtain a health-based guide for $\mathrm{Ag}$ in drinking water, $\mathrm{Ag}$ levels up to $0.1 \mathrm{mg} / \mathrm{L}$ can be tolerated.

\section{Conclusion}

Chitosan formed a colorless film and a matrix enabling nano-Ag particles to deposit homogeneously on the fabric surface. Chitosan source was effective in the quality of chitosan coatings. Crayfish chitosan may be more suitable for more homogeneous and thinner coatings. These properties are sought after in textiles and indicate that chitosan is appropriate to be used as a finishing agent in textiles. Also, the method used to coat fabrics is applicable to the long length and it is a useful method. It can be applied to the industry due to its ease of use and low cost.

Since the JIS L 1902 method allows comparative evaluation of the antibacterial activity of treated and untreated fabrics, it increases the reliability of the results and is considered to be a suitable method for testing 
antibacterial activity. A very strong antibacterial effect (99.99\% reduction) was obtained against $E$. coli bacteria on pre-treated cotton fabric surfaces with the effect of both nano-Ag particles and chitosan. Chitosan nano-Ag coating which exhibited a good antibacterial activity can be used in the manufacture of garments such as medical textiles, baby clothes, and underwear because of its sterility, due to its biocompatible, biodegradable, nontoxic and sterilizable properties.

Chitosan nano-Ag coating used as finishing contributes to the protection of human health by reducing the use of antibiotics. The evaluation of shrimp and crayfish wastes as chitosan also contributes to the protection of the environment. Besides, the chemical ratio can be reduced by the use of chitosan instead of binder,

\section{References}

1. Abdou, S.E., Nagy, K.S.A. \& Elsabee, M.Z. 2008. Extraction and characterization of chitin and chitosan from local sources. Bioresource Technology, 99(5): 1359-1367.

2. Akaydın, M. \& Kalkancı, M. 2014. A research on antibacterial properties of woven fabrics using for hospital clothing. SDU Journal of Science (E-Journal), 9(1): 20-34.

3. Anitha, A., Sowmya, S., Sudheesh Kumar, P.T., Deepthi, S., Chennazhi, K.P., Ehrlich, H., Tsurkan, M. \& Jayakumar, R. 2014. Chitin and chitosan in selected biomedical applications. Progress in Polymer Science, 39(9): 1644-1667.

4. Arif, D., Niazi, M.B.K., Ul-Haq, N., Anwar, M.N. \& Hashmi, E. 2015. Preparation of antibacterial cotton fabric using chitosan-silver nanoparticles. Fibers and Polymers, 16(7): 1519-1526.

5. Arrouze, F., Essahli, M., Rhazi, M., Desbrieres, J. \& Tolaimate, A. 2017. Chitin and chitosan: Study of the possibilities of their production by valorization of the waste of crustaceans and cephalopods rejected in Essaouira. Journal of Materials and Environmental Sciences, 8: 22512258.

6. Becenen, N. \& Altun, Ö. 2016. Applications of TiO2, ZnO and $\mathrm{Ag}$ nano materials to denim fabric. Journal of Nanoscience and Nanotechnology, 16(5): 5359-5363.

7. Burdusel, A.C., Gherasim, O., Grumezescu, A.M., Mogoanta, L., Ficai, A. \& Andronescu, E. 2018. Biomedical applications of silver nanoparticles: An up-todate overview. Nanomaterials, $8,681$. https://doi.org/10.3390/nano8090681.

8. Chattopadhyay, D. \& Inamdar, M.S. 2013. Improvement in properties of cotton fabrich through sythesized nanochitosan application. Indian Journal of Fibre \& Textile Research, 38: 14-21.

9. Chen, Q., Jiang, H., Ye, H., Li, J. \& Huang, J. 2014. Preparation, antibacterial, and antioxidant activities of silver/chitosan composites. Journal of Carbohydrate Chemistry, 0: 1-15.

10. Colclasure, V.J., Soderquist, T.J., Lynch, T., Schubert, N., McCormick, D.S., Urrutia, E., Knickerbocker, C., McCord, D. \& Kavouras, J.H. 2015. Coliform bacteria, fabrics, and the which is commonly used in textile printing, pigment dyeing in finishing materials. Purification processes can be reduced and thus cost is reduced. By structuring a clean production approach in textile enterprises and sustainable use of natural resources, it is possible to prevent or reduce pollutant discharges and emissions from industrial sources. Thus, this approach offers innovative solutions for the protection of human and environmental health.

\section{Acknowledgement}

This study was supported financially by Trakya University Reseach Fund with the project TUBAP 2018/198. The analyses were performed in the Trakya University Technology Research Development Application and Research Center (TUTAGEM) laboratories.

environment. American Journal of Infection Control, 43: 154-158.

11. Dahmane, E.M., Taourirte, M., Eladlani, N. \& Rhazi, M. 2016. Preparation and characterization of $\alpha$-chitin whiskers, chitosan, nanoparticles and chitosan nanoscaffold from Parapenaeus longirostris. Materials Today: Proceedings, 3: 2590-2598.

12. Dash, M., Chiellini, F., Ottenbrite, R.M. \& Chiellini, E. 2011. Chitosan-a versatile semi-synthetic polymer in biomedical applications. Progress in Polymer Science, 36: 981-1014.

13. Dutta, P.K., Dutta, J. \& Tripathi, V.S. 2004. Chitin and chitosan: chemistry, properties and applications. Journal of Scientific and Industrial Research, 63: 20-31.

14. Edwards Jones, V. 2009. The benefits of silver in hygiene, personal care and healthcare. Letters in Applied Microbiology, 49(2): 147-152.

15. Erdogan, S. \& Kaya, M. 2016. High similarity in physicochemical properties of chitin and chitosan from nymphs and adults of a grasshopper. International Journal of Biological Macromolecules, 89: 118-126.

16. Erdogan, S., Kaya, M. \& Akata, I. 2017. Chitin extraction and chitosan production from cell wall of two mushroom species (Lactarius vellereus and Phyllophora ribis). AIP Conference Proceedings, 1809: 020012. https://doi.org/10.1063/1.4975427.

17. Fan, Q., Maa, J., Xua, Q., Ana, W. \& Qiua, R. 2018. Multifunctional coatings crafted via layer-by-layer spraying method. Progress in Organic Coatings, 125: 215221.

18. Focher, B., Naggi, A., Torri, G., Cosani, A. \& Terbojevich, M. 1992. Structural differences between chitin polymorphs and their precipitates from solutions-evidence from $\mathrm{CP}$ MAS, ${ }^{13}$ CNMR, FT-IR and FT-Raman spectroscopy. Carbohydrate Polymers, 17: 97-102.

19. Gharibshahi, L., Saion, E., Gharibshahi, E., Shaari, A.H. \& Matori, K.A. 2017. Structural and optical properties of $\mathrm{Ag}$ nanoparticles synthesized by thermal treatment method. Materials, 10: 402. https://doi.org/10.3390/ma10040402. 
20. Govindan, S., Nivethaa, E.A.K., Saravanan, R., Narayanan, V. \& Stephen, A. 2012. Synthesis and characterization of chitosan-silver nanocomposite. Applied Nanoscience, 2: 299-303.

21. Hartemann, P., Hoet, P., Proykova, A., Fernandes, T., Baun, A., De Jong, W., Filser, J., Hensten, A., Kneuer, C., Maillard, J. Y., Norppa, H., Scheringer, M. \& Wijnhoven, S. 2015. Nanosilver: Safety, health and environmental effects and role in antimicrobial resistance. Materials Today, 18(3): 1369-7021.

22. Islam, S. \& Butola, B.S. 2019. Recent advances in chitosan polysaccharide and its derivatives in antimicrobial modification of textile materials. International Journal of Biological Macromolecules, 121: 905-912.

23. JIS L 1902: 2015. Japanese Industry Standard for Testing Antibacterial Activity and Efficiency in Textile Products.

24. Jiang, S.X., Qin, W.F., Guo, R.H. \& Zhang, L. 2010. Surface functionalization of nanostructured silver-coated polyester fabric by magnetron sputtering. Surface and Coatings Technology, 204: 3662-3667.

25. Korani, M., Rezayat, S.M. \& Arbabi Bidgoli, S. 2013. Subchronic dermal toxicity of silver nanoparticles in guinea pig: special emphasis to heart, bone and kidney toxicities. Iranian Journal of Pharmaceutical Research, 12: 511-519.

26. Korani, M., Ghazizadeh, E., Korani, S., Hami, Z. \& Mohammadi-Bardbori, A. 2015. Effects of silver nanoparticles on human health. European Journal of Nanomedicine, 7(1): 51-62.

27. Kumirska, J., Weinhold, M.X., Thoming, J. \& Stepnowski, P. 2011. Biomedical activity of chitin/chitosan based materials influence of physicochemical properties apart from molecular weight and degree of $\mathrm{N}$-acetylation. Polymers, 3: 1875-1901.

28. Lavall, R.L., Assis, O.B.G. \& Campana, S.P. 2007. Betachitin from the pens of Loligo sp.: Extraction and characterization. Bioresource Technology, 98: 2465-2472.

29. Li, C.W., Wang, Q., Li, J., Hu, M., Shi, S.J., Li, Z.W., Wu, G.L., Cui, H.H., Li, Y.Y. \& Zhang, Q. 2016. Silver nanoparticles/chitosan oligosaccharide/poly(vinyl alcohol) nanofiber promotes wound healing by activating TGF $\beta 1 /$ Smad signaling pathway. International Journal of Nanomedicine, 11: 373-387.

30. Liang, S., Sun, Y. \& Dai, X. 2018. A review of the preparation, analysis and biological functions of chitooligosaccharide. International Journal of Molecular Sciences, 19, 2197. https://doi.org/10.3390/ijms19082197.

31. Marambio Jones, C. \& Hoek, E.M.V. 2010. A review of the antibacterial effects of silver nanomaterials and potential implications for human health and the environment. Journal of Nanoparticle Research, 12: 1531-1551.

32. Morones, J.R., Elechiguerra, J.L., Camacho, A., Holt, K., Kouri, J.B., Ramírez, J.T. \& Yacaman, M.J. 2005. The bactericidal effect of silver nanoparticles. Nanotechnology, 16: 2346-2353.

33. Mujtaba M., Kaya, M., Bulut, E. \& Akyuz, B. 2016. Recycling and physicochemical characterization of pomegranate waste peels into a green material (cellulose), 448-456. Paper presented at the International Conference on Natural Science and Engineering (ICNASE'16), 19-20 March, Kilis-Turkey.

34. Murugan, K., Anitha, J., Suresh, U., Rajaganesh, R., Panneerselvam, C., Aziz, A.T., Tseng, L.C., Kalimuthu, K., Alsalhi, M.S., Devanesan, S., Nicoletti, M., Sarkar, S.K., Benelli, G. \& Hwang, J.S. 2017. Chitosan-fabricated Ag nanoparticles and larvivorous fishes: a novel route to control the coastal malaria vector Anopheles sundaicus? Hydrobiologia, 797(1): 335-350.

35. Palamutçu, S., Şengül, M., Devrent, N. \& Keskin, R. 2008. Tekstil ürünlerinde antimikrobiyal etkinlik belirleme testleri, 25-33. Paper presented at the VII. Ulusal Ölçümbilim Kongresi, 30 Ekim-1 Kasım 2008, İzmir, Turkey.

36. Panácek, A., Kvítek, L., Prucek, R., Kolár, M., Vecerová, R., Pizúrová, N., Sharma, V.K., Nevecná, T. \& Zboril, R. 2006. Silver colloid nanoparticles: synthesis, characterization, and their antibacterial activity. The Journal of Physical Chemistry B, 110: 16248-16253.

37. Pevzner, H. 2018. What is E. coli? Symptoms, treatment, prevention, and more. (https://www.everydayhealth.com/ecoli/), (Date accessed: 17.11.2019).

38. Pinho, E., Magalhães, L., Henriques, M. \& Oliveira, R. 2011. Antimicrobial activity assessment of textiles: standard methods comparison. Annals of Microbiology, 61: 493-498.

39. Rehan, M., El-Naggara, M.E., Mashaly, H.M. \& Wilken, R. 2018. Nanocomposites based on chitosan/silver/clay for durable multi-functional properties of cotton fabrics. Carbohydrate Polymers, 182: 29-41.

40. Rinaudo, M. 2006. Chitin and chitosan: properties and applications. Progress in Polymer Science, 31(7): 603-632.

41. Rivero, P.J., Urrutia, A., Goicoechea, J. \& Arregui, F.J. 2015. Nanomaterials for functional textiles and fibers. Nanoscale Research Letters, 10: 501. https://doi.org/10.1186/s11671-015-1195-6.

42. Scacchetti, F.A.P., Pinto, E. \& Soares, G.M.B. 2018. Thermal and antimicrobial evaluation of cotton functionalized with a chitosan-zeolite composite and microcapsules of phase-change materials. Journal of Applied Polymer Science, 135: 46135. https://doi.org/10.1002/app.46135.

43. SCENIHR, 2014. Opinion on nanosilver: safety, health and environmental effects and role in antimicrobial resistance. (https://ec.europa.eu/health/scientific_committees/emergin g/docs/scenihr_o_039.pdf), (Date accessed: 20 November 2019)

44. Sher, F., Malik, A. \& Liu, H. 2013. Industrial polymer effluent treatment by chemical coagulation and flocculation. Journal of Environmental Chemical Engineering, 1: 684-689.

45. Song, Y.S., Kim, Y.M.W., Moon, C., Seo, D.J., Han, Y.S., Jo, Y.H., Noh, M.Y., Park Y.K., Kim, S.A., Kim, Y.W. \& Jung, W.J. 2018. Extraction of chitin and chitosan from larval exuvium and whole body of edible mealworm, Tenebrio molitor. Entomological Research, 48: 227-233.

46. Souza, J., Matos, J., Fernandes, M., Zille, A. \& Fangueiro, R. 2017. Coated chitosan onto gauze to efficient conditions 
for maintenance of the wound microenvironment. Procedia Engineering, 200: 135-140.

47. Şahan, G. \& Demir, A. 2016. Tekstil terbiyesinde nano boyutta kitosanın yeşil uygulaması. Tekstil ve Konfeksiyon, 26 (4): 414-420.

48. Tania, I.S., Ali, M. \& Azam, S. 2019. In-situ synthesis and characterization of silver nanoparticle decorated cotton knitted fabric for antibacterial activity and improved dyeing performance. SN Applied Sciences, 1: 64. https://doi.org/10.1007/s42452-018-0068-x.

49. Torlak, E. 2008. Measurement uncertainty in testing for antimicrobial activity on textile materials. Accreditation and Quality Assurance, 13: 563-566.

50. Xu, Q.B., Zheng, W.S., Duan, P.P., Chen, J.N., Zhang, Y.Y., Fu, F.Y, Diao, H.Y. \& Liu, X.D. 2019. One-pot fabrication of durable antibacterial cotton fabric coated with silver nanoparticles via carboxymethyl chitosan as a binder and stabilizer. Carbohydrate Polymers, 204: 42-49.

51. Velmurugan, P., Lee, S.M., Cho, M., Park, J.H., Seo, S.K., Myung, H., Bang, K.S. \& Oh, B.T. 2014. Antibacterial activity of silver nanoparticle-coated fabric and leather against odor and skin infection causing bacteria. Applied Microbiology and Biotechnology, 98: 8179-8189.

52. Wang, C., Lv, J., Ren, Y., Zhou, Q., Chen, J., Zhi, T., Lu, Z., Gao, D., Ma, Z. \& Jin, L. 2016. Cotton fabric with plasma pretreatment and $\mathrm{ZnO} /$ Carboxymethyl chitosan composite finishing for durable UV resistance and antibacterial property panel. Carbohydrate Polymers, 138: 106-113.

53. Wiegand, C., Abel, M., Ruth, P., Elsner, P. \& Hipler, U.C. 2015. In vitro assessment of the antimicrobial activity of wound dressings: influence of the test method selected and impact of the $\mathrm{pH}$. Journal of Material Science: Materials in Medicine, 26:18. https://doi.org/10.1007/s10856-0145343-9.

54. WHO 2017. Guidelines for drinking-water quality. (https://apps.who.int/iris/bitstream/handle/10665/254637/ 9789241549950eng.pdf;jsessionid=A112FD355F734FD1 A58FA2048FE0CBA1? sequence=1), (Date accessed: 26 November 2019)

55. Zhang, H., Yun, S., Song, L., Zhang, Y. \& Zhao, Y. 2017. The preparation and characterization of chitin and chitosan under large-scale submerged fermentation level using shrimp by-products as substrate. International Journal of Biological Macromolecules, 96: 334-339.

56. Zhao, D., Yu, S., Sun, B., Gao, S., Guo, S. \& Zhao, K. 2018. Biomedical applications of chitosan and its derivative nanoparticles. Polymers, 10(4): 462. https://doi.org/10.3390/polym10040462

57. Zhou, C.E. \& Kan, C.W. 2014. Plasma-assisted regenerable chitosan antimicrobial finishing for cotton. Cellulose, 21: 2951-2962. 